\title{
Spectrometric analysis and scanning electronic microscopy of two pleural plaques from mediaeval Portuguese period
}

\author{
T. Fernandes ${ }^{a, b, *}$, R. Granja ${ }^{a}$, P.L. Thillaud ${ }^{c}$ \\ a Departamento de Biologia, Escola de Ciências e Tecnologia, Universidade de Évora, 7002-554, Portugal

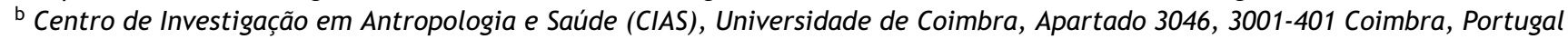 \\ c École des Hautes Étude, Section des Sciences Historiques et Philologiques, La Sorbonne, Paris, France
}

Received 29 August 2013; accepted 10 January 2014

Available online 21 June 2014

\section{KEYWORDS}

Calcified soft tissue; Infectious disease; Mediaeval Portuguese cemetery;

Pleural plaques

\section{PALAVRAS-CHAVE}

Tecidos moles calcificados; Doença infeciosa; Cemitério mediaeval português;

Placas pleurais

\begin{abstract}
During an archaeological excavation at a mediaeval monastery (Flor da Rosa, Crato, Portugal), a skeleton of a adult woman was found with two calcifications in the thoracic cage. The location and the macroscopic analysis of the calcifications allowed them to be assigned as pleural plaques. Spectrometric analysis and scanning electronic microscopy enabled to establish that it originated with an infectious process. These results associated with the lesions found in the ribs and vertebrae strongly suggest tuberculosis as the cause of these pleural plaques. (C) 2013 Sociedade Portuguesa de Pneumologia. Published by Elsevier España, S.L.U. All rights reserved.
\end{abstract}

Análise espectrométrica e microscopia eletrónica de varrimento de 2 placas pleurais do período mediaeval Português

Resumo Durante uma escavação arqueológica de um mosteiro mediaeval (Flor da Rosa, Crato, Portugal) foi encontrado um esqueleto de uma mulher adulta, com 2 calcificações na caixa torácica. A localização e a análise macroscópica das calcificações permitiu que fossem consideradas como placas pleurais. A análise espectrométrica e a microscopia eletrónica de varrimento permitiram determinar que tiveram origem num processo infecioso. Estes resultados, associados com as lesões encontradas nas costelas e vértebras, sugerem nitidamente a tuberculose como causa dessas placas pleurais.

(C) 2013 Sociedade Portuguesa de Pneumologia. Publicado por Elsevier España, S.L.U. Todos os direitos reservados.

\footnotetext{
* Corresponding author.

E-mail address: tmf@uevora.pt (T. Fernandes).
}

0873-2159/\$ - see front matter @ 2013 Sociedade Portuguesa de Pneumologia. Published by Elsevier España, S.L.U. All rights reserved. 


\section{Introduction}

Two pleural plaques (pathological calcifications of soft tissues) were found in the thoracic cage of the skeletal remains of a woman (FR 857), exhumed at the necropolis of the "Mosteiro da Flor da Rosa"' (Crato, Portugal), during an archaeological excavation at this mediaeval monastery. The excavation took place between 1989 and 1992 and revealed about one hundred graves inside and around the church. The coins that accompanied some of the burials, which constituted almost the only grave goods, gave a dating for the cemetery between the XIV to the XIX centuries. The skeletons were found in a supine position, their lower limbs were extended and their upper limbs were folded according to Christian ritual practices.

Using infra-red spectroscopy and scanning electronic microscopy to identify the mineral content grades, the structure of the pleural plaque surface and the elemental composition, we suggest that the plaques had an infectious origin, as discussed below. In spite of the fact that the skeleton was in a poor state and incomplete, other interesting pathological lesions were observed: new bone formation on the pleural face of ribs and vertebral body osteolysis.

As far as we know pleural plaques are not a common finding on archaeological series: there are one from Israel, ${ }^{1}$ two in France, ${ }^{2}$ three in Switzerland, ${ }^{3-5}$ one in Slovakia, ${ }^{6}$ two in Hungary, one from Bácsalmás ${ }^{7,8}$ and the second from Pitvaros $^{7}$. All of these pleural plaques, except the one from Bácsalmás, which is reported to date from the $17^{\text {th }}$ century, were mediaeval. The oldest is dated from the 6th century (Saint-Denis, France) and the most recent from the 15th century (Bina, Slovakia). Although the exact dating of the present case is not confirmed, according to the archaeological report ${ }^{9}$ its stratigraphy strongly suggests the 15 th century.

The aim of this study was to describe the pleural plaques and to identify the most probable aetiology.

\section{Material and methods}

Sex and age diagnoses were performed according to Buikstra \& Ubelaker ${ }^{10}$ recommendations.
After studying both pleural plaques macroscopically, two samples were taken from the most irregular surface of one of them (fragment II - Fig. 1A and B): one sample of the edge and one sample of the inner side. In order to quantify mineral composition, these samples were analysed by infra-red spectroscopy (Fourier transform IR spectroscopy, according to Pavia et al. ${ }^{11}$ ) by Dr. M. Daudon at the Biochemistry Laboratory of the "Hôpital Necker-Enfants Malades" (Paris). Each portion of the bone was ground, mixed with potassium bromide and pressed into pellets, which subsequently were analysed.

\section{Results}

Observation of this poorly preserved skeleton of a woman revealed, in addition to the pleural plaque, deposits of new bone in the pleural surfaces of the ribs, presenting a striated aspect, as well as some lytic lesions in several thoracic vertebral bodies.

Macroscopic observation of the plaques revealed the following features: solid, mineral, thin with spiculated margins, slightly bent (especially the larger one), irregular granular external convex side, smooth and striated internal concave side.

The spectroscopic analysis revealed a similar composition between the edge and the inner side of the plaque fragment (Fig. $2 \mathrm{~A}$ and B; Fragment II).

The following main mineral and organic components were found:

1 Carbapatite, usually detected in the band of $1034 \mathrm{~cm}^{-1}$, displayed by far the highest values in both graphs.

2 Crystalline apatite, commonly detected in the ranges between $564 \mathrm{~cm}^{-1}$ and $605 \mathrm{~cm}^{-1}$, corresponded to the second highest values obtained.

3 The third highest values plotted in our graphs corresponded to a residual protein framework, identified by the bands of $1545 \mathrm{~cm}^{-1}$ (starch band 2) and $1650 \mathrm{~cm}^{-1}$ (starch band 1) usually connected to CoNH bounds, revealing the good conservation of the $\mathrm{CH}$ amino acids.

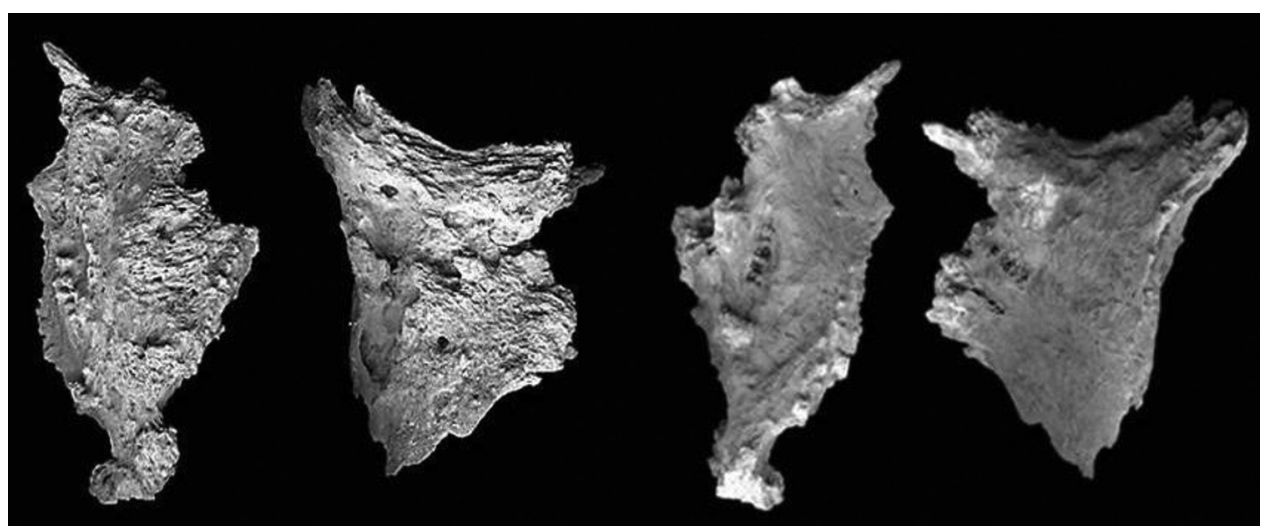

Figure 1 (A) Pleural plaques, external convex side. From left to right: Fragment I; Fragment II (true size). (): Pleural plaques, internal concave side. From left to right: Fragment I; Fragment II (true size). Maximum length, maximum width and average thickness of fragments I and II are, respectively: $64.43 / 34.14 / 6.86 \mathrm{~mm}$ and 55.46/43.43/7.8 mm. Scanning electron microscopy (Hitachi TM $3000, \mathrm{SU}-70,30 \mathrm{keV}$ ) was performed to study the pleural plaques surface and its element composition. Because both fragments were found in the same skeleton and show similar macroscopic aspects, only one of them was analysed. 

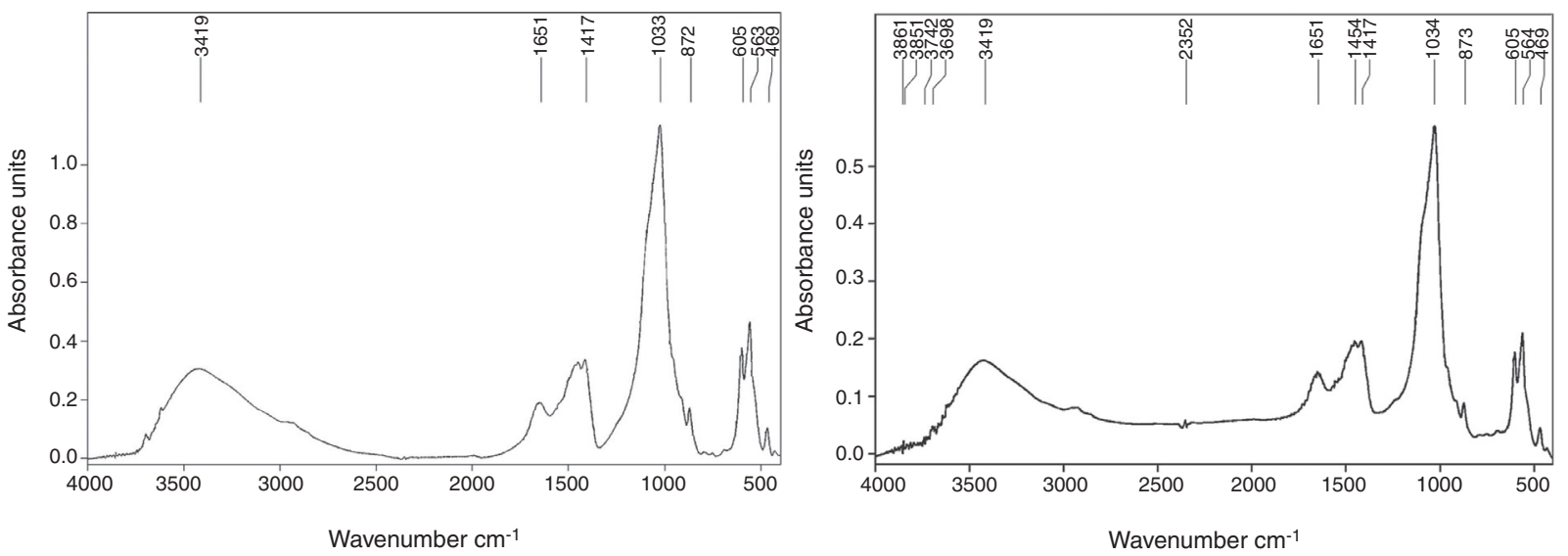

Figure 2 (A) Spectroscopic analysis of the plaque edges. (B) Spectroscopic analysis of the plaque inner side.

Although $\mathrm{CH}$ bounds seem well preserved, the amount of proteins still present in the plaques was not particularly high, as shown by the $2860 \mathrm{~cm}^{-1}$ and $2960 \mathrm{~cm}^{-1}$ lines. Phosphates were detected in the $500 \mathrm{~cm}^{-1}$ band.

SEM image enabled us to see clusters of granules covering almost the entire pleural plaque surface (Fig. 3).

This technique also provided the approximate element concentration of the plaque surface: oxygen $56.0 \%$; calcium $15.9 \%$; phosphorus $11.1 \%$; silico $5.8 \%$; aluminium $5.1 \%$; sodium $2.0 \%$; iron $1.5 \%$; magnesium $1.1 \%$; potassium $0.8 \%$; chlorine $0.3 \%$ and sulfur $0.2 \%$.

\section{Discussion and conclusions}

Differences in surface roughness and orientation of the mineralizations on external and internal surfaces of the plaques

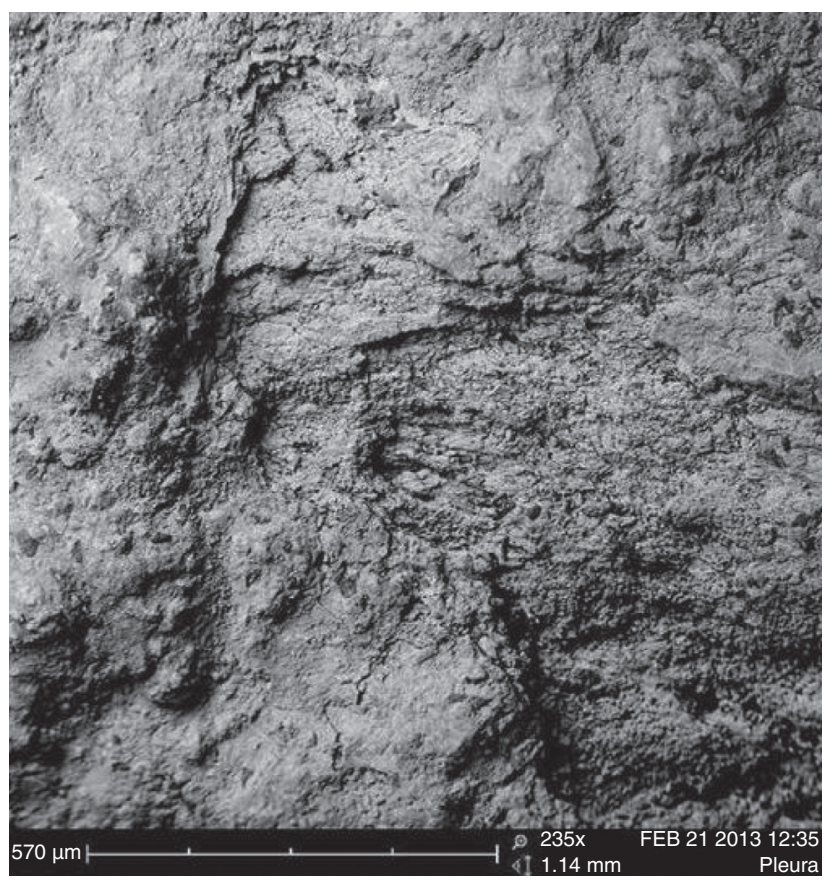

Figure 3 Scanning electronic microscopy of the pleural plaque surface $(235 \times)$. presumably result from pleural mechanics. They are due to respiratory movements in the presence of a liquid medium during solidification.

The striking morphological similarity between the two plaques suggests that they probably originated from one complete pleural plaque.

The low level of crystallization, revealed by the low amount of apatite, is observable in the intensity report, by the distance separating the peak $1034 \mathrm{~cm}^{-1}$ and the slope $1100 \mathrm{~cm}^{-1}$, which excludes a possible confusion with an artefact triggered by post-mortem conditions. ${ }^{2}$ Moreover, the crystal network of the apatite remains moderately developed (peaks at $564 \mathrm{~cm}^{-1}, 605 \mathrm{~cm}^{-1}$ ), suggesting that the formation occurred not long before the death of the individual. These observations also led us to assume that the infection was active at the moment of death.

Concerning the aetiology of the plaque, the absence of amosite, chrysotile and crocidolite, which are the specific minerals for asbestos, excludes asbestosis as the cause of this pleural plaque. A post-traumatic cause characterized by a calcified haematoma should also be excluded, since there were no traces of hematite and the recorded protein proportion was rather low. ${ }^{2}$ The exclusion of a strictly taphonomic origin of this calcification lies in the difference in the macroscopic morphology of the inner and outer surfaces which results from respiratory mechanics, and in the presence of $\mathrm{CH}$ and proteins in the spectrogram.

The high amount of carbonate ions incorporated in the apatite matrix (30\% carbapatite) strongly points to the infectious origin of this pleural plaque, as carbapatite reflects the classic inflammation process. The buildup of inflammatory granuloma dominated by fibrosis tends to calcify and forms carbapatite, which in turn tends to crystallize. ${ }^{12,13}$

The relative element concentration provided by scanning electron microscopy shows an $\mathrm{O}, \mathrm{Ca}, \mathrm{P}$ molar ratio of $4: 1: 1$ which seems to be compatible with the presence of calcium phosphate (carbapatite), and thus backs up the spectrometric analysis.

Macroscopically both plaques showed changes typical of an infectious origin: the rough side, spiculated, and the smooth side, striated. ${ }^{2,8}$ It is worth noting the great macroscopical similarity of these plaques to those ascribed to tuberculosis in the literature. In some cases, the agent was confirmed by molecular biology. ${ }^{7,8}$ 
The formation of new bone on the ribs combined with the presence of lytic lesions on several vertebral bodies is usually associated with infectious processes, which strengthens the hypothesis that tuberculosis is related to the origin of these calcifications.

Although molecular analysis could make a helpful contribution to the identification of the aetiology of these pleural plaques, it was not performed in this study due to the absence of several conditions regarded as essential for credibility. Among them are the facts that the collection of specimens at the excavation site was not performed under sterile conditions, and the taphonomic factors that might impact on preservation of ancient DNA were not strictly controlled. ${ }^{14,15}$

The non-renewable nature of archaeological remains, the uncertainty of DNA survival and the rarity of pleural plaques were all significant factors in the decision to not carry out potentially destructive molecular diagnosis at this point.

\section{Ethical disclosures}

Protection of human and animal subjects. The authors declare that no experiments were performed on humans or animals for this study.

Confidentiality of data. The authors declare that no patient data appear in this article.

Right to privacy and informed consent. The authors declare that no patient data appear in this article.

\section{Authors' contributions}

TF and RG collected the macroscopical data for sex and age diagnosis and for characterization of the plaques and related lesions. PT provided access to spectrometric analysis and its interpretation. All the authors contributed to the final conception of the manuscript.

\section{Conflicts of interest}

The authors have no conflicts of interest to declare.

\section{Acknowledgements}

We thank Dr. M. Daudon of the Biochemistry Laboratory of the Hôpital Necker-Enfants Malades (INSERM U $90)$, Paris, for the analysis of the pleural plaque material, and VWR Portugal for scanning electronic microscope utilization.

\section{References}

1. Donoghue HD, Spigelman M, Zias J, Gernaey-Child AM, Minnikin DE. Mycobacterium tuberculosis complex DNA in calcified pleura from remains 1400 years old. Lett Appl Microbiol. 1998;27:265-9.

2. Hadjouis D, Thillaud P. Analyse de plaques pleurales calcifiées provenant des nécropoles médiévales. Étude de deux cas. Biometrie Hum Anthropol. 1997;15:31-41.

3. Kramar C. Plaques pleurales chez un homme du Moyen Age: étude radiologique, microscopique et cristallographique. In: Capecchi V, Rabino Massa E, editors. Proceedings of the V European meeting of the paleopathology association. 1984. $\mathrm{p}$. 199-210.

4. Baud CA. Une plaque pleurale calcifiée: étude ultrastructurale et cristallographique, Geneva; 1972. XX: 196-9.

5. Baud CA, Kramar C. Soft tissue calcifications in paleopathology. In: Ortner DJ, Aufderheide AC, editors. Human paleopathology. Current synthesis and future options. Washington and London: Smithsonian Institution Press; 1991. p. 87-9.

6. Thurzo M, Vihnanek L. Petrifikované utvary z hrudnj dutinz jedinca zo stredovekého pohrebiska $v$ Bini, okres Nove Zamky [Petrified particles from the thoracic cavity of an individual of the medieval cemetery at Bina, district Nové Zamky]. Cas Nar Muz Praze. 1983;152:145-7.

7. Haas ChJ, Zink A, Molnár E, Marcsik A, Dutour O, Nerlich GA, et al. Molecular evidence for tuberculosis in Hungarian skeletal samples. In: Pálfi GY, Dutour O, Deák J, Hutás I, editors. Tuberculosis past and present. Budapest: Golden Book Publisher; 1999. p. 385-95.

8. Haas CJ, Zink A, Molnar E, Szeimies U, Reischl U, Marcsik A, et al. Molecular evidence for different stages of tuberculosis in ancient bone samples from Hungary. Am J Phys Anthropol. 2000;113:293-304.

9. Gonçalves A. Intervenção Arqueológica no Mosteiro de Flor da Rosa (1989-1992). Relatório da Intervenção. IPPAR; 1993 [Unpublished].

10. Buikstra JE, Ubelaker DH. Standards for data collection from human skeletal remains. In: Proceedings of a seminar at the field museum of natural history. Arkansas Archaeological Survey Research Series 44. Fayettevile, Arkansas. 1994.

11. Pavia DL, Lampman GM, Kriz GS. Introduction to spectroscopy. Brooks Cole; 2000.

12. Lagier R, Baud CA, Buchs M. Crystallographic identification of calcium deposits as regards their pathological nature, with special reference to chondrocalcinosis. In: Fleisch $\mathrm{H}$, Blackwood HJJ, Owen M, editors. Third European symposium on calcified tissues. Springer; 1966. p. 151-62.

13. Lagier R, Baud CA. Magnesium whitlockite, a calcium phosphate crystal of special interest in pathology. Pathol Res Pract. 2003;199:329-35.

14. Roberts C, Ingham S. Using ancient DNA analysis in palaeopathology: a critical analysis of published papers, with recommendations for future work. Int J Osteoarchaeol. 2008; 18:600-13.

15. Wilbur AK, Bouwman AS, Stone AC, Roberts CA, Pfister LA, Buikstra JE, et al. Deficiencies and challenges in the study of ancient tuberculosis DNA. J Archaeol Sci. 2009;36:1990-7. 